RHINOLOGY

\title{
Multiple gene expression profiling suggests epithelial dysfunction in polypoid chronic rhinosinusitis
}

\author{
Il profilo di espressione genica multipla rivela una disfunzione epiteliale \\ nella rinosinusite cronica polipoide
}

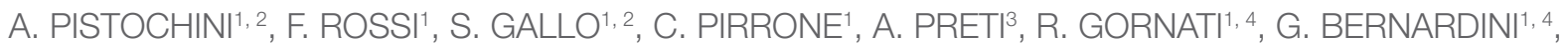 \\ P. CASTELNUOVO ${ }^{1,2}$
}

${ }^{1}$ Department of Biotechnology and Life Sciences, University of Insubria, Varese, Italy; ${ }^{2}$ Department of Otorhinolaryngology, University of Insubria and ASST Sette Laghi, Varese, Italy; ${ }^{3}$ Department of Otorhinolaryngology, University of Milan and IRCCS Multimedica, Ospedale San Giuseppe, Milan, Italy; 4 "The Protein Factory" Research Center, Politecnico of Milano, ICRM-CNR Milan and University of Insubria, Milan, Italy

\section{SUMMARY}

Chronic rhinosinusitis (CRS) is a heterogeneous inflammatory disorder resulting from a complex gene-environment interaction. Although its aetiology remains elusive, numerous studies reported gene expression alterations of factors apparently implicated in all aspects of the inflammatory response. However, most investigations are limited, unconfirmed analyses of a single gene. Moreover, studies concerning multiple gene expression analyses, usually on inflammatory mediators (e.g. cytokines), show contrasting outcomes in part due to use of heterogeneous samples or methodologies with limited power. In this scenario, our goal was to simultaneously evaluate the expression of a panel of selected genes (AQP5, MUC5AC, CAV1, LTF, COX2, PGDS, TNF $\alpha, T G F \beta 1, M G B 1)$ potentially involved in CRS inflammatory mechanisms. While most of the samples collected were excluded from the analysis because of poor quality RNA, we were able to demonstrate statistically significant downregulation of the AQP5, CAV1, LTF, MGB1 genes in a specific subset of polypoid CRS (patients without typical comorbidities), which might suggest relevant underlying epithelial dysfunction. Further studies are needed to enrich our knowledge on the pathogenesis of CRS. Forthcoming approaches might utilise next-generation RNA sequencing and comprehensive bioinformatics analyses to better characterise the transcriptome profiles of CRS endotypes.

KEY WORDS: Chronic rhinosinusitis $\bullet$ Nasal polyps $\bullet$ qPCR $\bullet$ Epithelial damage $\bullet$ Inflammatory cytokines $\bullet$ Tissue remodelling $\bullet$ Immune barrier

\section{RIASSUNTO}

La rinosinusite cronica (CRS) è un disturbo infiammatorio eterogeneo risultante da una complessa interazione genetico-ambientale. Sebbene l'eziologia rimanga tuttora sfuggente, numerosi studi riportano alterazioni nell'espressione genica di diversi fattori implicati nell'ambito della risposta infiammatoria. Tuttavia, la gran parte di queste sono analisi isolate, non replicate, che prendono in considerazione un singolo gene alla volta. Inoltre, gli studi riguardanti analisi di espressione genica multipla, solitamente su mediatori infiammatori (es. citochine), spesso presentano risultati contrastanti, che in parte possono essere dovuti all'eterogeneità dei campioni o a metodologie analitiche di potenza limitata. In quest'ottica, il nostro obiettivo è stato di verificare simultaneamente l'espressione genica di un pannello di geni (AQP5, MUC5AC, CAV1, LTF, COX2, PGDS, TNF $\alpha, T G F \beta 1$, MGB1) potenzialmente coinvolti nei meccanismi infiammatori della CRS. Nonostante la gran parte dei campioni sia stata esclusa dall'analisi a causa del deterioramento dell'RNA tissutale, siamo stati in grado di dimostrare una riduzione statisticamente significativa dell'espressione dei geni AQP5, CAV1, LTF e MGB1, in uno specifico sottogruppo di pazienti affetti da CRS nella variante con polipi nasali senza le tipiche comorbidità frequentemente associate (asma, allergia, intolleranza all'acido acetil-salicilico). Questi dati sembrano suggerire una disfunzione della barriera epitaliale nella CRS polipoide. Ulteriori studi saranno necessari per incrementare ulteriormente la nostra conoscenza sulla patogenesi della CRS. A tal proposito l'applicazione delle nuove e più potenti tecniche di sequenziamento, come la next-generation RNA sequencing, e la disponibilità di analisi bioinformatiche più complete potranno migliorare la caratterizzazione del transcriptoma negli endotipi della CRS.

PAROLE CHIAVE: Rinosinusite cronica $\bullet$ Poliposi nasale $\bullet$ PCR $・$ Disfunzione epiteliale $\bullet$ Citochine infiammatorie $\bullet$ Rimodellamento tissutale $\bullet$ Barriera immunitaria 


\section{Introduction}

Chronic rhinosinusitis (CRS) is a heterogeneous disorder characterised by persistent symptomatic inflammation of the nasal and paranasal sinus mucosa.

The interest of research in CRS arises from several factors. First, CRS is one of the most commonly reported diseases, estimated as the second most prevalent chronic health condition and affecting $10.9 \%$ of the European population. Second, the burden of CRS to society is considerable, with substantial negative impact on several aspects of quality of life and considerable medical costs. Lastly, the current treatment options struggle to be widely effective ${ }^{1}$.

The aetiology of CRS remains unclear. It is becoming widely accepted that CRS arises from genetic, epigenetic, microbial and environmental factors; several conditions, such as asthma, damage of ciliated mechanical barrier, obstruction of nasal drainage, induction of inflammatory cytokines and impairment of the immune system, have been recognised as predisposing or associated factors to CRS ${ }^{1}$. For these reasons, current research has attempted to elucidate the factors leading to persistent sinus inflammation, focusing on innate and acquired immunological mechanisms ${ }^{2}$.

Numerous studies have reported alterations in the gene expression of factors apparently implicated in all aspects of the inflammatory response. However, most investigations are limited, unconfirmed analyses of a single gene. In addition, studies concerning multiple gene expression analyses, usually on inflammatory mediators (e.g. cytokines), demonstrate contrasting outcomes in part due to heterogeneous samples or methodologies with limited power ${ }^{3}$.

Furthermore, even the site of tissue sampling seems to influence the results; indeed, there is evidence of a topographic gene expression in the sinonasal cavities. In particular, nasal polyps in CRS have been shown to exhibit a unique transcriptional pattern, typical of the polypoid tissue itself and not simply related to chronic mucosal inflammation or regional variations ${ }^{4}$. In this scenario, our goal was to simultaneously evaluate, in healthy samples and CRS with nasal polyps (CRSwNP), the expression of a panel of genes involved in: (1) defects in the epithelial barrier and in both innate and adaptive host defence functions (Aquaporin 5-AQP5, Mucin 5AC-MUC5AC, Caveolin 1-CAV1, Lactoferrin-LTF); (2) alterations of eicosanoid pathways (Cyclooxygenase 2-COX2, Prostaglandin D Synthase- $P G D S$ ); and (3) induction of inflammatory cytokines and aberrant remodelling processes (Tumour necrosis factor alpha-TNF $\alpha$, Transforming growth factor beta 1-TGF $\beta 1$, Mammaglobin 1-MGB1). Inclusion criteria for CRS patients were tight and painstaking and care was taken in collecting tissue samples in order to minimise the above-mentioned distortions.

\section{Materials and methods}

\section{Participants}

A retrospective study was carried out on a total of 85 individuals, comprising 52 cases (CRSwNP) and 33 controls (CTL). The local Institutional Review Board approved this study. All participants provided informed consent to use their samples for research purposes. Research was carried out in compliance with the Helsinki Declaration.

As the case group, we recruited patients affected by CRSwNP as defined by the European guidelines ${ }^{1}$, aged from 18 to 75 years. All cases presenting with immune-deficiency, autoimmune diseases, genetic disorders, history of sinonasal trauma, tumours, or loco-regional radiotherapy were excluded. Moreover, only CRSwNP patients without asthma, allergy, aspirin sensitivity, or hyper-eosinophilia $(>10 \%)$ were considered suitable for enrolment.

As the control group, we recruited subjects undergoing nasal surgery for other reasons (septoplasty, turbinoplasty, skull base reconstruction after trauma, spontaneous cerebrospinal fluid leaks, endoscopic approaches to sellar region), matched to patients for age and sex. We adjusted the control selections for geographic region and ethnicity in order to minimise the environmental differences with the cases. Exclusion criteria consisted of a positive history of asthma, allergy and acute or chronic rhinosinusitis.

\section{Sample collection}

Arbitrarily, 20 days before surgery patients suspended local steroid treatment in order to dispose of "pharmacological wash-out" mucosal samples, eliminating the potential effects of steroids on gene expression. At the time of surgery, the absence of acute inflammatory and infectious conditions was verified both in patients and controls. Biopsy specimens of CRSwNP and CTL mucosa were obtained from the anterior ethmoid (uncinate process or bulla ethmoidalis, when available) under general or local anaesthesia and immediately stored at $-80^{\circ} \mathrm{C}$ until further analysis.

\section{RNA extraction and reverse transcription}

Total RNA was isolated from $100 \mathrm{mg}$ of tissue using the TRIzol solution (Invitrogen ${ }^{\mathrm{TM}}$, Italy) according the standard protocol. The extracted RNA was quantified by 
QuantiFluor fluorometer (Promega, Italy) using QuantiFluor $^{\circledR}$ RNA System dye and its quality and integrity was assessed by $1 \%$ gel electrophoresis. The first strand cDNA was synthesised using the iScript ${ }^{\mathrm{TM}}$ cDNA Synthesis Kit (BioRad, Italy), according to the manufacturer's instructions and stored at $-20^{\circ} \mathrm{C}$.

\section{Quantitative PCR}

For quantitative PCR (qPCR), six genes were chosen as housekeeping genes (glyceraldehyde-3-phosphate dehydrogenase-GAPDH, beta- 2 microglobulin- $\beta 2 \mathrm{M}$, hypoxanthine phosphoribosyltransferase 1-HPRT1, Actin_beta-Actin $\beta$, TATA box binding protein-Tbp and ribosomal protein L13-RPL13) and the most stable three genes (GAPDH, $\beta 2 \mathrm{M}$ and $A c t i n \beta)$ were selected according to Palombella et al. ${ }^{5}$. Selected target genes are reported in Table I. qPCR was performed using iTaq ${ }^{\mathrm{TM}}$ Universal SYBR ${ }^{\circledR}$ GreenSupermix (BioRad, Italy). Specific primers were designed using the Beacon Designer Program (BioRad, Italy) within the sequences of the genes shown in Table II. Each reaction was performed according to Rossi et al. ${ }^{6}$. Briefly, $7.5 \mu \mathrm{l}$ of SYBR Green Supermix (2x), $1 \mu \mathrm{l}$ of forward and reverse primers $(6 \mu \mathrm{M}), 5 \mathrm{ng}$ of cDNA and water to a final volume of $15 \mu \mathrm{l}$ were mixed and run in a CFX 96 Thermocycler (BioRad, Italy). The thermal cycle was as follows: $5 \mathrm{~min}$ at $95^{\circ} \mathrm{C}, 10 \mathrm{sec}$ at $95^{\circ} \mathrm{C}$ and $30 \mathrm{sec}$ at $60^{\circ} \mathrm{C}$ for 40 cycles. Each experiment was repeated three times.

\section{Statistical analysis}

Comparative cycle threshold method $(\Delta \mathrm{Ct})$ was used for qPCR analysis and gene levels expressed as $2^{-\Delta \mathrm{Ct}}$ $(\Delta \mathrm{Ct}=\mathrm{CtTarget}-\mathrm{CtHousekeeping})$. Data analysis were performed by Student's t-test. Results were statistically significant with $p<0.05$.

\section{Results}

Despite the large number of samples processed and the maximum care during the sample collection and manipulation, we encountered much difficulty in obtaining good quality RNA from biopsies; among the 85 selected individuals (52 CRSwNP and 33 CTL), only a total of 24 samples, comprising $11 \mathrm{CRSwNP}$ and $13 \mathrm{CTL}$, were considered suitable for the study, due to extraction of poorquality RNA.

As can be seen in agarose gel electrophoresis of specimens from both CRSwNP and CTL Groups (Figs. 1, 2), in some samples the RNA appeared to be partially degraded. This occurred particularly in CRSwNP specimens (Fig. 1), showing that the problem was probably due to the extraction of pathologic tissue with poor cellular content.

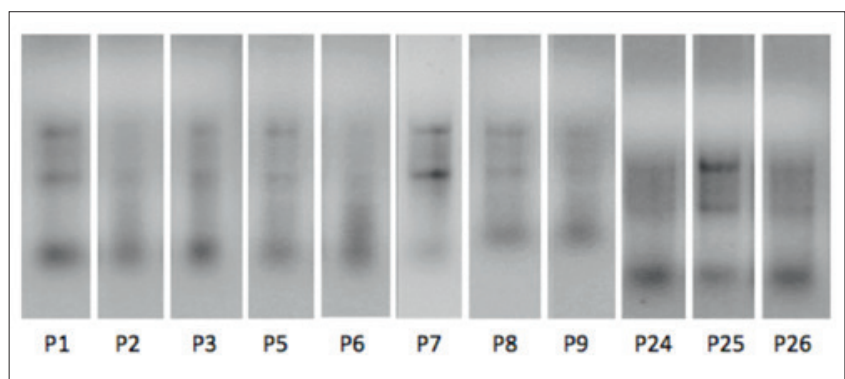

Fig. 1. 1\% Agarose gel electrophoresis of some specimens of CRSwNP Group, in which RNA is seen to be partially degraded.

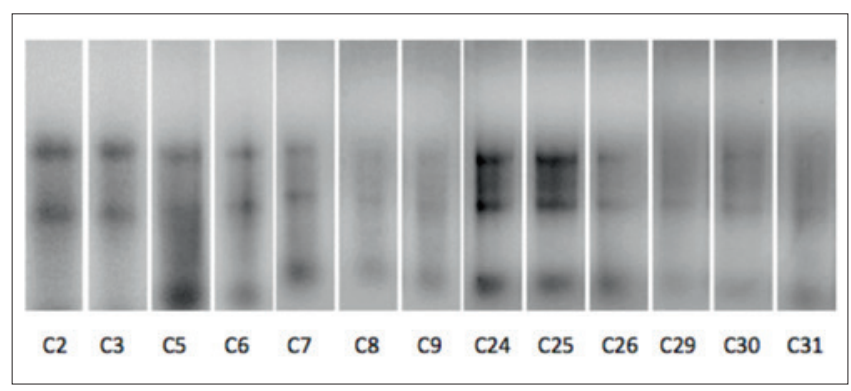

Fig. 2. 1\% Agarose gel electrophoresis of specimens of the CTL Group in which RNA is less degraded compared to pathological tissue.

This problem was clearly less evident in biopsies taken from healthy mucosa from CTL Group (Fig. 2).

In the first group of selected genes, those related to the epithelial barrier and immune functions, $A P Q 5, C A V 1$ and $L T F$ genes were significantly downregulated in CRSwNP samples compared to CTLs, as reported in Figure 3 $(p<0.05)$. In the other two groups of genes, statistically significant downregulation was observed for $C O X 2$ and MGB1 genes in CRSwNP samples compared to CTLs $(p<0.05)$, as reported in Figures 4 and 5, respectively.

\section{Discussion}

It is increasingly acknowledged that CRS is not a single pathological entity, but has a rather broad clinical presentation, histopathology and response to therapy. Several pathophysiological pathways seem to exist, ending in the common point of sinonasal mucosal inflammation. Once chronic inflammation has become apparent, the activation of other pathways inevitably masks the possibility to identify the early cause. Determining which cellular and molecular characteristics of CRS represent the underlying factors that induce inflammation, or more simply the downstream consequences, remains a challenge in the ongoing field of research ${ }^{7}$.

In this context, in the attempt to give our contribution 
Table I. Target genes selected for qPCR analysis.

\begin{tabular}{|c|c|c|c|c|c|}
\hline Gene title & Gene symbol & Family & Subcellular localisation & Molecular functions & $\begin{array}{l}\text { Gene ontology biological } \\
\text { process }\end{array}$ \\
\hline Aquaporin 5 & AQP5; PPKB & $\begin{array}{l}\text { MIP/aquaporin (TC } \\
\text { 1.A.8) }\end{array}$ & $\begin{array}{l}\text { Apical cell membrane; } \\
\text { Multi-pass membrane }\end{array}$ & $\begin{array}{l}\text { Water channel activity; } \\
\text { protein binding }\end{array}$ & $\begin{array}{l}\text { Transport; water transport; } \\
\text { excretion; carbon dioxide } \\
\text { transport; pancreatic juice } \\
\text { secretion }\end{array}$ \\
\hline Mucin 5AC & $\begin{array}{l}\text { MUC5AC; LeB; } \\
\text { TBM }\end{array}$ & Mucins & Secreted & $\begin{array}{l}\text { Extracellular matrix } \\
\text { structural constituent }\end{array}$ & $\begin{array}{l}\text { Stimulatory C-type lectin } \\
\text { receptor signalling pathway; } \\
\text { 0-glycan processing; } \\
\text { phosphatidylinositol-mediated } \\
\text { signalling }\end{array}$ \\
\hline Caveolin 1 & $\begin{array}{l}\text { CAV1; MSTP085; } \\
\text { BSCL3; LCCNS; } \\
\text { VIP21; CGL3; } \\
\text { PPH3 }\end{array}$ & Caveolin & $\begin{array}{l}\text { Golgi apparatus } \\
\text { membrane; peripheral } \\
\text { cell membrane }\end{array}$ & $\begin{array}{l}\text { Receptor binding; } \\
\text { patched binding; } \\
\text { structural molecule } \\
\text { activity; protein binding; } \\
\text { cholesterol binding }\end{array}$ & $\begin{array}{l}\text { Negative regulation of } \\
\text { transcription from RNA } \\
\text { polymerase II promoter; } \\
\text { MAPK cascade; inactivation of } \\
\text { MAPK activity; angiogenesis; } \\
\text { vasculogenesis }\end{array}$ \\
\hline Lactoferrin & $\begin{array}{l}\text { LTF; GIG12; EC } \\
3.4 .21 ; \text { HEL110; } \\
\text { HLF2 }\end{array}$ & Transferrin & $\begin{array}{l}\text { Secreted; cytoplasmic } \\
\text { granule; cytoplasm }\end{array}$ & $\begin{array}{l}\text { Lipopolysaccharide } \\
\text { binding; DNA } \\
\text { binding; serine- } \\
\text { type endopeptidase } \\
\text { activity; cysteine-type } \\
\text { endopeptidase inhibitor } \\
\text { activity; iron ion binding }\end{array}$ & $\begin{array}{l}\text { Ossification; regulation of } \\
\text { cytokine production; retina } \\
\text { homeostasis; innate immune } \\
\text { response in mucosa; immune } \\
\text { system process }\end{array}$ \\
\hline Cyclooxygenase 2 & $\begin{array}{l}\text { COX2; PHS } \\
\text { II; PGHS-2; } \\
\text { EC 1.14.99; } \\
\text { GRIPGHS; PGG/ } \\
\text { HS; HCox-2; } \\
\text { PHS-2 }\end{array}$ & $\begin{array}{l}\text { Prostaglandin } \mathrm{G} / \mathrm{H} \\
\text { synthase }\end{array}$ & $\begin{array}{l}\text { Microsome membrane; } \\
\text { peripheral membrane; } \\
\text { endoplasmic reticulum } \\
\text { membrane; }\end{array}$ & $\begin{array}{l}\text { Peroxidase activity; } \\
\text { prostaglandin- } \\
\text { endoperoxide synthase } \\
\text { activity; protein } \\
\text { binding; lipid binding; } \\
\text { oxidoreductase activity }\end{array}$ & $\begin{array}{l}\text { Prostaglandin biosynthetic } \\
\text { process; angiogenesis; lipid } \\
\text { metabolic process; fatty acid } \\
\text { metabolic process; } \\
\text { fatty acid biosynthetic process }\end{array}$ \\
\hline $\begin{array}{l}\text { Prostaglandin D } \\
\text { Synthase }\end{array}$ & $\begin{array}{l}\text { PGDS; EC } \\
\text { 5.3.99.2; PGDS2 } \\
\text { PDS; L-PGDS; } \\
\text { LPGDS; PGD2 }\end{array}$ & Lipocalins & $\begin{array}{l}\text { Rough endoplasmic } \\
\text { reticulum; nucleus } \\
\text { membrane; Golgi } \\
\text { apparatus; cytoplasm, } \\
\text { perinuclear region; } \\
\text { Secreted. }\end{array}$ & $\begin{array}{l}\text { Prostaglandin-D } \\
\text { synthase activity; } \\
\text { transporter activity; } \\
\text { retinoid binding; fatty } \\
\text { acid binding; protein } \\
\text { binding }\end{array}$ & $\begin{array}{l}\text { Prostaglandin metabolic and } \\
\text { biosynthetic process; lipid } \\
\text { metabolic process; fatty acid } \\
\text { metabolic and biosynthetic } \\
\text { process; }\end{array}$ \\
\hline $\begin{array}{l}\text { Tumour necrosis } \\
\text { factor alpha }\end{array}$ & $\begin{array}{l}\text { TNF } \alpha ; \text { TNFSF2; } \\
\text { TNFA; APC1; } \\
\text { TNLG1F; DIF }\end{array}$ & $\begin{array}{l}\text { Tumour necrosis } \\
\text { factor }\end{array}$ & Cell membrane & $\begin{array}{l}\text { Protease binding; } \\
\text { cytokine activity; } \\
\text { tumour necrosis factor } \\
\text { receptor binding; } \\
\text { protein binding }\end{array}$ & $\begin{array}{l}\text { Protein import into nucleus, } \\
\text { translocation; negative } \\
\text { regulation of transcription from } \\
\text { RNA polymerase II promoter; } \\
\text { MAPK cascade; activation of } \\
\text { MAPK activity }\end{array}$ \\
\hline $\begin{array}{l}\text { Transforming growth } \\
\text { factor beta } 1\end{array}$ & $\begin{array}{l}\text { TGF } \beta 1 \text {; DPD1; } \\
\text { LAP; CED }\end{array}$ & Endogenous ligands & $\begin{array}{l}\text { Secreted; extracellular } \\
\text { space; extracellular } \\
\text { matrix }\end{array}$ & $\begin{array}{l}\text { Glycoprotein binding; } \\
\text { antigen binding; type } \\
\text { II transforming growth } \\
\text { factor beta receptor } \\
\text { binding; cytokine } \\
\text { activity; transforming } \\
\text { growth factor beta } \\
\text { receptor binding }\end{array}$ & $\begin{array}{l}\text { Protein import into nucleus, } \\
\text { translocation; negative } \\
\text { regulation of transcription } \\
\text { from RNA polymerase II } \\
\text { promoter; MAPK cascade; } \\
\text { vasculogenesis; ureteric bud } \\
\text { development }\end{array}$ \\
\hline Mammaglobin 1 & $\begin{array}{l}\text { MGB1; SCGB2A; } \\
\text { UGB2 }\end{array}$ & Secretoglobin & $\begin{array}{l}\text { Secreted; Extracellular } \\
\text { matrix }\end{array}$ & Protein binding & Biological process \\
\hline
\end{tabular}

to better clarify and understand the molecular patterns involved in CRS, we selected healthy and CRSwNP individuals and investigated the expression of several key genes involved in crucial points of CRS pathogenesis.
Despite the attention during tissue collection by the surgeon, the expertise of the laboratory technician in manipulating tissue and the care taken in all the steps to preserve the quality and the integrity of biological samples, 
Table II. Primers used for qPCR analysis.

\begin{tabular}{|c|c|c|c|c|}
\hline Gene Name & & Sequence 5'-3' & Melting Temperature $\left({ }^{\circ} \mathrm{C}\right)$ & Sequence Accession Number \\
\hline \multirow[t]{2}{*}{ GAPDH } & FW Primer & ATCATCAGCAATGCCTCCT & 60.9 & \multirow{2}{*}{ M17851.1 } \\
\hline & Rev Primer & GAGTCCTTCCACGATACCAA & 60.5 & \\
\hline \multirow[t]{2}{*}{$\beta 2 \mathrm{M}$} & FW Primer & CTATCCAGCGTACTCCAA & 59.5 & \multirow{2}{*}{ AF072097.1 } \\
\hline & Rev Primer & GAAACCCAGACACATAGC & 59.5 & \\
\hline \multirow[t]{2}{*}{ Actin $\beta$} & FW Primer & ATGGGTCAGAAGGATTCC & 59.8 & \multirow{2}{*}{ NM_001101.3 } \\
\hline & Rev Primer & CTCGATGGGGTACTTCAG & 60.3 & \\
\hline \multirow[t]{2}{*}{ AQP5 } & FW Primer & GCTCAACAACAACACAACG & 62.1 & \multirow{2}{*}{ NM_001651.3 } \\
\hline & Rev Primer & TCAGTGGAGGCGAAGATG & 62.9 & \\
\hline \multirow[t]{2}{*}{ CAV1 } & FW Primer & TGAGCGAGAAGCAAGTGTAC & 64.2 & \multirow{2}{*}{ BT007143.1 } \\
\hline & Rev Primer & GTCATCGTTGAGGTGTTTAGGG & 65.1 & \\
\hline \multirow[t]{2}{*}{$\operatorname{cox} 2$} & FW Primer & GTCTGGTGCCTGGTCTGA & 65.3 & \multirow{2}{*}{ M90100.1 } \\
\hline & Rev Primer & GTCTGGAACAACTGCTCATCA & 64.5 & \\
\hline \multirow[t]{2}{*}{ MGB1 } & FW Primer & GAAGTTGCTGATGGTCCTC & 62.0 & \multirow{2}{*}{ NM_002411.3 } \\
\hline & Rev Primer & TTGTGGATTGATTGTCTTGGA & 61.7 & \\
\hline \multirow[t]{2}{*}{ MUC5AC } & FW Primer & САTAACTTGTGGTCCTGGAACTA & 63.9 & \multirow{2}{*}{ L46721.1 } \\
\hline & Rev Primer & CCGAGATTGTGCTGGTTGTA & 64.2 & \\
\hline \multirow[t]{2}{*}{ PGDS } & FW Primer & TGTAACTTGGGCAGACTTCTACT & 65.3 & \multirow{2}{*}{ NM_014485.2 } \\
\hline & Rev Primer & GCAGGAATGGCTTGGACTT & 64.6 & \\
\hline \multirow[t]{2}{*}{ TNF $\alpha$} & FW Primer & ATGGCGTGGAGCTGAGAG & 65.3 & \multirow{2}{*}{ HQ201306.2 } \\
\hline & Rev Primer & TGAAGAGGACCTGGGAGTAGAT & 65.8 & \\
\hline \multirow[t]{2}{*}{ TGF $\beta 1$} & FW Primer & CTCGCCAGAGTGGTTATC & 65.9 & \multirow{2}{*}{ NM_000660.5 } \\
\hline & Rev Primer & GTGTTATCCCTGCTGTCA & 65.4 & \\
\hline \multirow[t]{2}{*}{ LTF } & FW Primer & CTAATCTCTGTGCTCTGTGTATTG & 63 & \multirow{2}{*}{ M93150.1 } \\
\hline & Rev Primer & CCAGTGTAGCCGTAGTATCTC & 63.2 & \\
\hline
\end{tabular}

the present work showed some limitations. First, only 24 samples of the 85 collected were deemed suitable for the study due to poor-quality RNA. It is well known that RNA is very susceptible to degradation during sampling, handling and storage ${ }^{8}$. Moreover, previous studies demonstrated a higher concentration of RNases in nasal polyps compared to normal tissue as well as an increased enzyme activity 910 .

Second, the selection of patients was flawed by inclusion criteria established exclusively on a clinical basis (patients with polypoid CRS, either without asthma, allergic sensitization, aspirin intolerance or peripheral blood hypereosinophilia) when it is now clear that a clinical phenotypic differentiation does not adequately mirror the underlying immunological profile ${ }^{11}$. As a consequence, our results, though significant, should be interpreted in the light of this deliberate bias.

\section{Disrupted epithelium}

The "epithelial barrier hypothesis" of CRS pathogenesis indicates that an intact barrier with tight epithelial junctions is necessary for healthy nasal mucosa. Defects in this protective barrier, including the epithelium itself and its mucous lining, mucociliary clearance, intercellular junctions, ion channels and secreted antimicrobial proteins and enzymes, may cause the passage of pathogenic microbes across the epithelium and subsequent dysregulation of the inflammatory cascade ${ }^{12}$. With the aim of exploring epithelial barrier functionality, we chose to verify the expression of the AQP5, MUC5AC, CAV1 and LTF genes. As reported in Figure 3, the expression of all these genes in CRSwNP samples was downregulated compared to CTLs, and the differences in AQP5, CAVI and LTF were statistically significant (Fig. 3a-c).

In detail, $A Q P 5$ acts as a key tight junction in regulating water transport and cell volume and in maintaining water homeostasis in the epithelium ${ }^{2}$. In CRS, a downregulation of AQP5 has been associated with oedema and polyp formation and production of thick secretion, typical features of CRSwNP ${ }^{13}$ (Fig. 3a). 


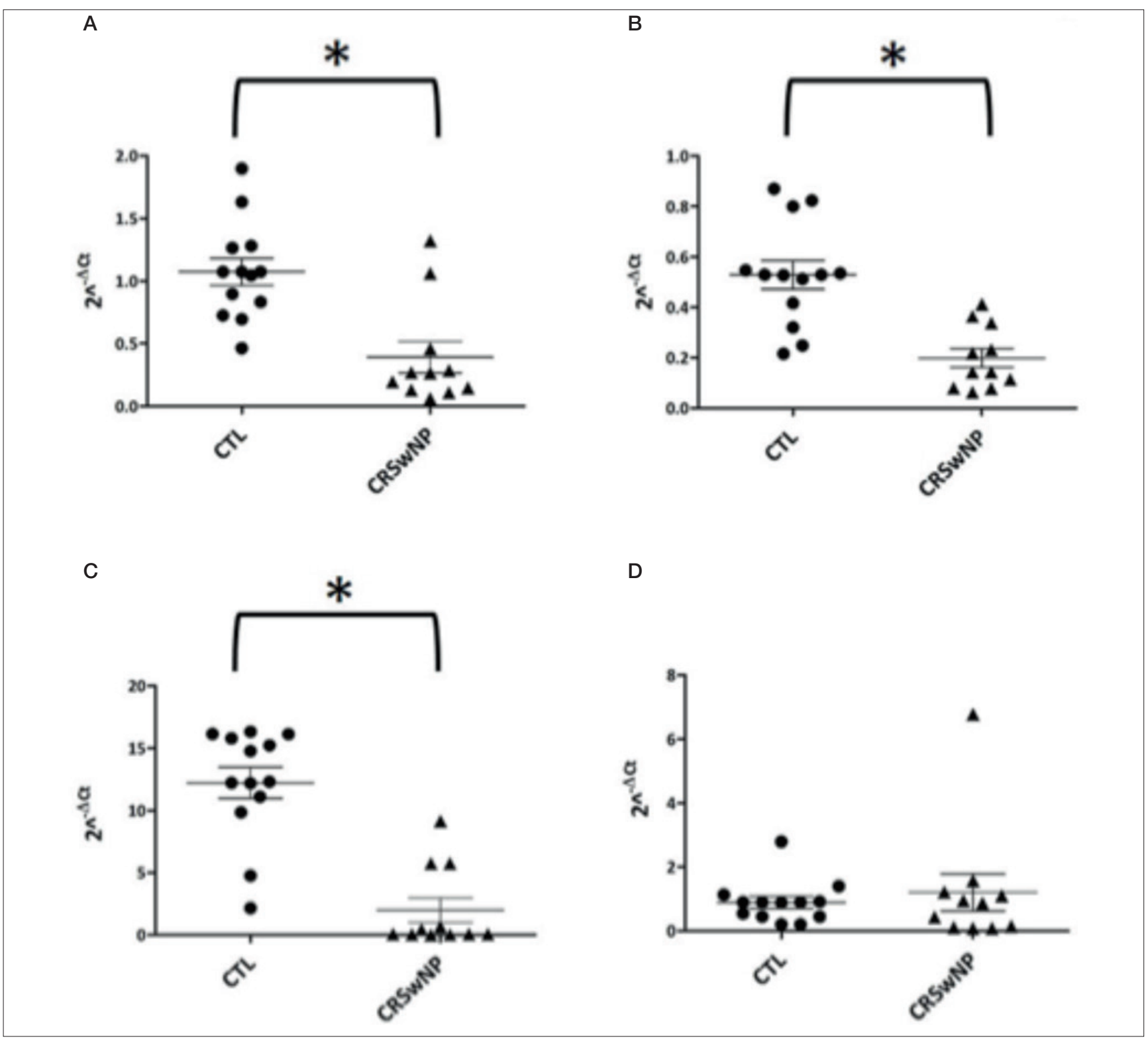

Fig. 3. Molecular expression of AQP5 (a), CAV1 (b), LTF (c) and MUC5AC (d) in healthy subjects (CTL) and in CRS patients with nasal polyps (CRSwNP) by qPCR. CTL: 13 cases; CRSwNP: 11 cases. (*) indicates statistically significant data $(p<0.05)$ obtained by Student's t-test.

CAV1 is a scaffolding membrane protein implicated in vesicular transport, endocytosis and regulation of signal transduction. Moreover, this gene plays a central role in defence against infections ${ }^{14}$. Downregulation of $C A V 1$ has been reported to cause dysregulation of membrane trafficking in the airway epithelium ${ }^{15}$ (Fig. 3b).

LTF possess diverse functions, including antibacterial, antifungal and antiviral activities, as well as immune regulatory and anti-inflammatory actions ${ }^{16}$. There is evidence that LTF is significantly decreased particularly in polypoid CRS patients with bacterial biofilms ${ }^{17}$ (Fig. 3c).
Taken together our results tend to confirm previous literature reports.

Contrarily, in our analysis, MUC5AC was slightly downregulated in CRSwNP compared to CTL, albeit with no significant difference. MUC5AC is one of the predominant gel-forming mucins in human nasal mucosa ${ }^{18}$ and its upregulation, induced by various stimuli such as bacteria and allergens, was found in CRSwNP subjects ${ }^{19}{ }^{20}$. Although the increased production of mucus allows for better trapping and clearance, mucin overproduction may lead to airway obstruction and exacerbation of pre-exist- 


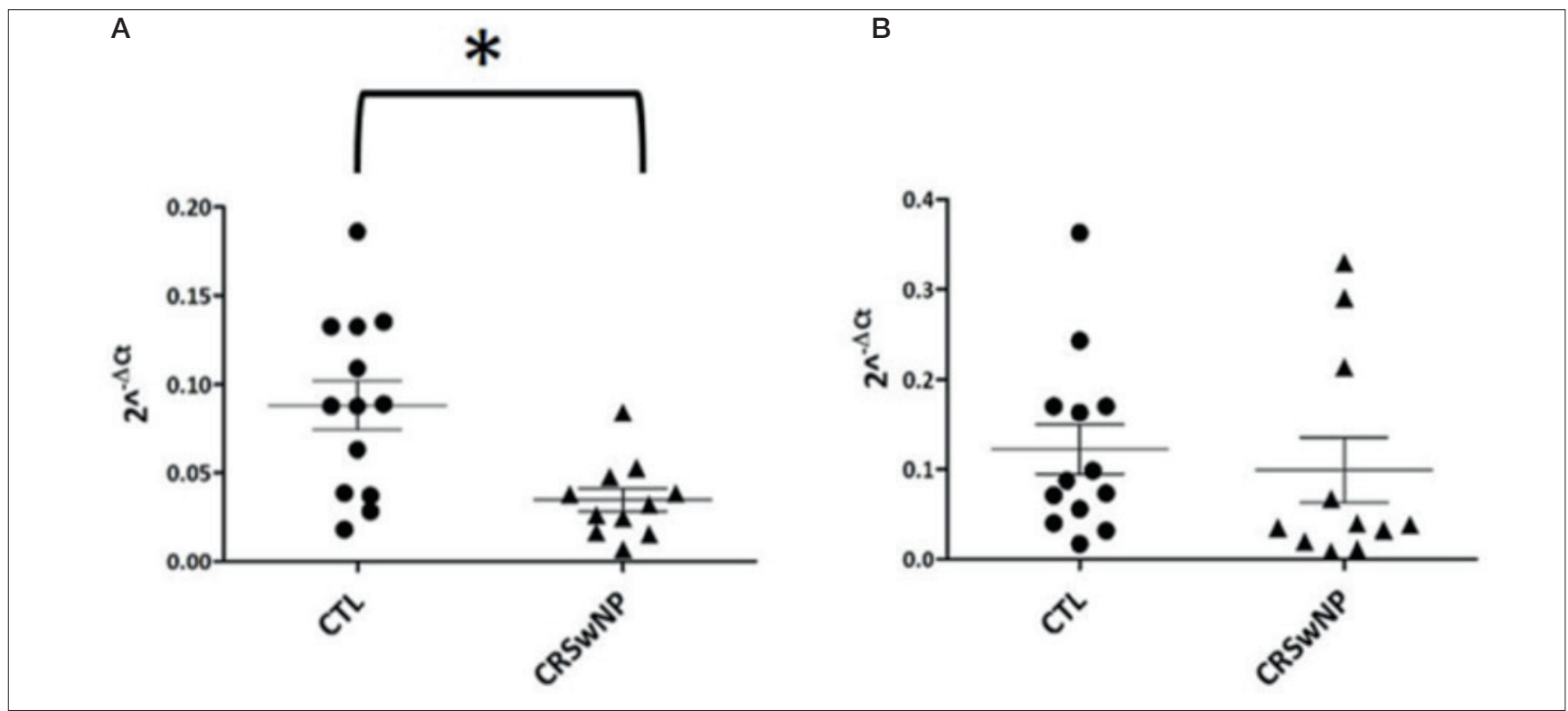

Fig. 4. Molecular expression of COX2 (a) and PGDS (b) genes in healthy subjects (CTL) and in CRS patients with nasal polyps (CRSwNP) by qPCR. CTL: 13 cases; CRSwNP: 11 cases. $\left(^{\star}\right)$ indicates data statistically significant $(p<0.05)$ obtained by Student's t-test.
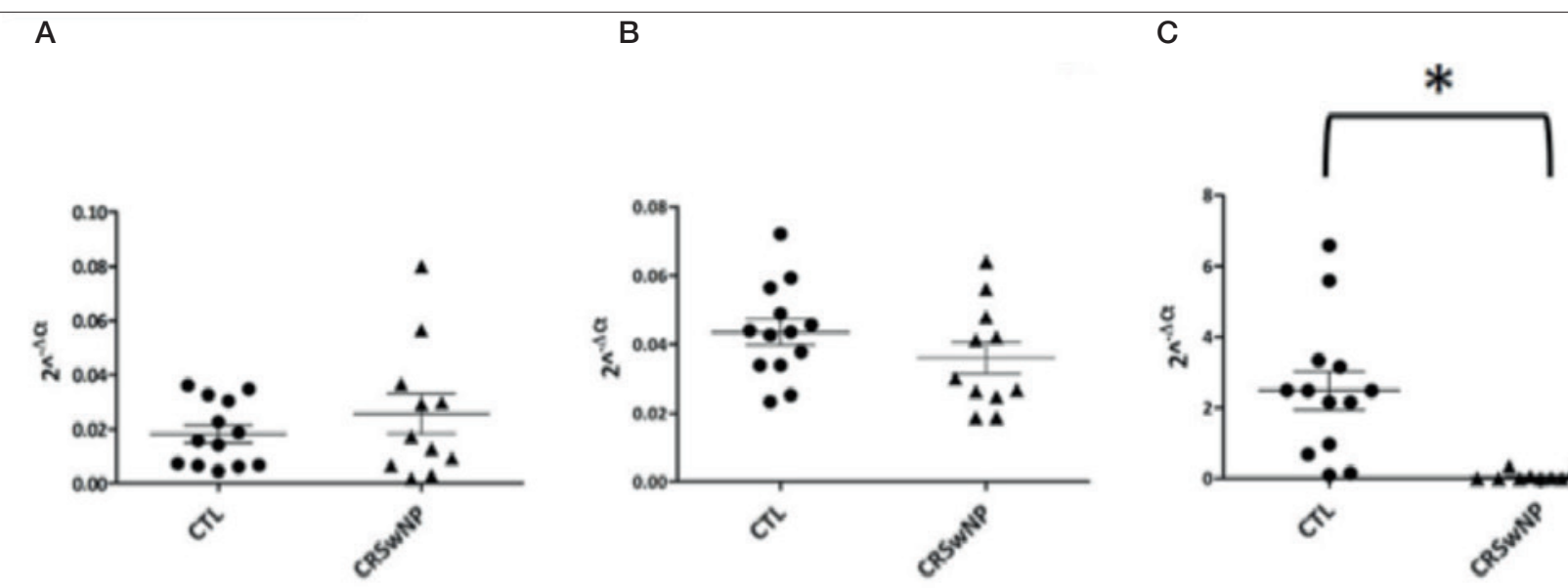

Fig. 5. Molecular expression of TNF $\alpha$ (a), TGF 1 (b) and MGB1 (c) genes in healthy subjects (CTL) and in CRS patients with nasal polyps (CRSwNP) by qPCR. CTL: 13 analysed cases; CRSwNP: 11 analysed cases. $\left(^{*}\right)$ indicates statistically significant data $(p<0.05)$ obtained by Student's t-test.

ing inflammation and infection ${ }^{21}$. Our data showed a single sample with a very high level of MUC5AC compared to the other 10 samples (Fig. 3d).

\section{Defects in eicosanoid metabolism}

Defects in eicosanoid metabolism, particularly involving leukotriene (LT) and prostaglandin (PG), seem to be asso- ciated to CRS, especially in the polyp variant. COX2 has a key role in the synthesis of biologically active prostaglandins that possess different functions ${ }^{22}$. For instance, prostaglandin D2 (PGD2) prolongs the survival of eosinophils and induces the migration of Th2 lymphocytes, whereas prostaglandin E2 (PGE2) stimulates bronchodilation and demonstrates anti-inflammatory effects by reducing 
the production of LTs. In CRSwNP, increased levels of PGD2 and PGD2 synthase (PGDS) were positively correlated with the eosinophil infiltrate ${ }^{23}$, and imbalance in PGD2/PGE2 metabolism contributes to CRS associated to aspirin intolerance ${ }^{24}$. In line with these findings, in our CRSwNP series, COX2 expression was significantly reduced (Fig. 4a). However, there are controversial reports in the literature on the behaviour of COX2 in CRS. It has been shown that COX2 mRNA displays different kinetics in nasal mucosa and nasal polyps, obliging us to consider that even the sampling site may affect the results ${ }^{25}$. The reduced expression (not significant) of $P G D S$, apparently in contrast to what previously reported, may be justified by the fact that our population did not include cases of aspirin intolerance, a clinical feature that appears to be strongly associated to eicosanoid metabolism imbalance in favour of the PGD2 cascade (Fig. 4b).

\section{Inflammatory cytokines and remodelling processes}

Numerous cytokines have been reported to be expressed at altered levels in CRSwNP tissues ${ }^{26}$. We decided to explore the inflammatory status, remodelling pattern and immune-modulating activities, respectively, through the analysis of expression of the $T N F \alpha, T G F \beta 1$ and $M G B 1$ genes (Fig. 5).

Increased levels of $T N F \alpha$ have already been demonstrated in nasal polyp tissues, together with other pro-inflammatory cytokines ${ }^{27}$, and protein levels are elevated in nasal secretion of CRSwNP patients ${ }^{28}$. Although not statistically significant compared to CTL, our CRSwNP samples showed overexpression of TNF $\alpha$ mRNA (Fig. 5a).

In CRS, chronic inflammation results in structural changes referred to as a remodelling process, which tends to balance extracellular matrix production and degradation by several regulation mediators, such as TGF $\beta 1$. Previous studies have confirmed its pivotal role in these processes, showing significantly lower expression of $T G F \beta 1$ in CRSwNP compared to controls ${ }^{26}{ }^{29}$. The downregulation signalling pathway results in oedema formation and lack of collagen production, histologic features that are typical of nasal polyps. $T G F \beta 1$ gene expression was also lower in our CRSwNP group, although a significant difference was not reached (Fig. 5b).

Lastly, our results showed a significant downregulation of the $M G B 1$ gene in CRSwNP samples compared to CTLs (Fig. 5c). The role of MGB1 in CRS remain uncertain, but it is known that other proteins of the mammaglobin family are secretory proteins involved in modulation of inflammatory processes, and $M G B 1$ overexpression in nasal polyps has been associated with neoplastic-like growth ${ }^{30}$.

\section{Conclusions}

The intent of the present study was to enrich data reported in the literature by analysing, at the same time, the expression of several genes implicated in various inflammatory aspects of CRSwNP. We believe that confirmatory studies are unavoidable in research which strengthen the current knowledge about CRS pathogenesis and allow better definition of endotypes in order to achieve "tailored" treatment ${ }^{31}$. Forthcoming approaches might take into account next-generation RNA sequencing and comprehensive bioinformatics analyses (e.g. hierarchical clustering) to characterise the transcriptome profiles of CRS subgroups. In summary, our attempt at gene expression profiling allowed us to depict a specific subset of CRSwNP (without typical comorbidities), which showed significant downregulation of APQ5, CAV1, LTF, COX2 and MGB1 genes, data that might suggest relevant epithelial dysfunction in polypoid chronic rhinosinusitis.

Difficulty in mRNA extraction has to be taken into account for future studies, and in this regard the synergy between surgeon and laboratory is of great importance; the surgeon must have full knowledge of what happens during laboratory processing and what is needed. Additional genes could be selected from the literature for similar studies, or the same genes could be retested. In any case, the present results need further study on larger samples.

\section{Acknowledgements}

Stefania Gallo is a PhD student of the "Biotechnology, Biosciences and Surgical Technology" course at University of Insubria. Cristina Pirrone is a post-doc funded by Fondazione Cariplo (Rif. 2013-1052). Andrea Preti is a PhD student of "Experimental and Translational Medicine" at University of Insubria.

\section{Conflict of interest statement}

None declared.

\section{References}

\footnotetext{
Fokkens WJ, Lund VJ, Mullol J, et al. European position paper on rhinosinusitis and nasal polyps 2012. Rhinol Suppl 2012;23:1-298.

2 Tieu DD, Kern RC, Schleimer RP. Alterations in epithelial barrier function and host defense responses in chronic rhinosinusitis. J Allergy Clin Immunol 2009;124:37-42.

3 Stevens WW, Ocampo CJ, Berdnikovs S, et al. Cytokines in chronic rhinosinusitis. role in eosinophilia and aspirin-exacerbated respiratory disease. Am J Respir Crit Care Med 2015;192:682-94.

4 Platt MP, Soler ZM, Kao SY, et al. Topographic gene expression in the sinonasal cavity of patients with chronic sinusitis with polyps. Otolaryngol Head Neck Surg 2011;145:171-5.
} 
5 Palombella S, Pirrone C, Cherubino M, et al. Identification of reference genes for qPCR analysis during hASC long culture maintenance. PLoS One 2017;12:e170918.

6 Rossi F, Palombella S, Pirrone C, et al. Evaluation of tissue morphology and gene expression as biomarkers of pollution in mussel Mytilus galloprovincialis caging experiment. Aquat Toxicol 2016;181:57-66.

7 Lee S, Lane AP. Chronic rhinosinusitis as a multifactorial inflammatory disorder. Curr Infect Dis Rep 2011;13:159-68.

8 Pérez-Novo CA, Claeys C, Speleman F, et al. Impact of RNA quality on reference gene expression stability. Biotechniques 2005;39:52-6.

9 Song KJ, Kim SK, Ahn KS, et al. Activities of enzymes involved in nucleic acid degradation in nasal polyp tissues. Korean J Otorhinolaryngol-Head Neck Surg 1986;29:485-96.

10 Nicolis E, Melotti P, Tamanini A, et al. Quantitative detection of CFTR mRNA in gene transfer studies in human, murine and simian respiratory tissues in vitro and in vivo. Gene Ther Mol Biol 1999;4:221-32

11 Tomassen P, Vandeplas G, Van Zele T, et al. Inflammatory endotypes of chronic rhinosinusitis based on cluster analysis of biomarkers. $\mathrm{J}$ Allergy Clin Immunol 2016;137:1449-56.

12 Kern RC, Conley DB, Walsh W, et al. Perspectives on the etiology of chronic rhinosinusitis: an immune barrier hypothesis. Am J Rhinol 2008;22:549-59.

13 Shikani AH, Sidhaye VK, Basaraba RJ, et al. Mucosal expression of aquaporin 5 and epithelial barrier proteins in chronic rhinosinusitis with and without nasal polyps. Am J Otolaryngol 2014;35:377-83.

14 Lin H, Lin D, Xiong XS, et al. Downregulation of caveolin-1 in chronic rhinosinusitis with and without nasal polyps. Eur Arch Otorhinolaryngol 2015;272:613-8.

15 Coyne CB, Vanhook MK, Gambling TM, et al. Regulation of airway tight junctions by proinflammatory cytokines. Mol Biol Cell 2002;13:3218-34.

16 Zhang Y, Lima CF, Rodrigues LR. Anticancer effects of lactoferrin: underlying mechanisms and future trends in cancer therapy. Nutr Rev 2014;72:763-73.

17 Psaltis AJ, Bruhn MA, Ooi EH, et al. Nasal mucosa expression of lactoferrin in patients with chronic rhinosinusitis. Laryngoscope 2007;117:2030-5.

18 Groneberg DA, Peiser C, Dinh QT, et al. Distribution of respiratory mucin proteins in human nasal mucosa. Laryngoscope 2003;113:520-4.
19 Fahy JV, Dickey BF. Airway mucus function and dysfunction. N Engl J Med 2010;363:2233-47.

20 Ding GQ, Zheng CQ. The expression of MUC5AC and MUC5B mucin genes in the mucosa of chronic rhinosinusitis and nasal polyposis. Am J Rhinol 2007;21:359-66.

21 Zhang N, Van Crombruggen K, Gevaert E, et al. Barrier function of the nasal mucosa in health and type-2 biased airway diseases. Allergy 2016;71:295-307.

22 Miłoński J, Zielińska-Bliźniewska H, Przybyłowska K, et al. Significance of Cyclooxygenase-2 (COX-2), Periostin (POSTN) and Interleukin-4 (IL-4) gene expression in the pathogenesis of chronic rhinosinusitis with nasal polyps. Eur Arch Otorhinolaryngol 2015;272:3715-20.

23 Hyo S, Kawata R, Kadoyama K, et al. Expression of prostaglandin D2 synthase in activated eosinophils in nasal polyps. Arch Otolaryngol Head Neck Surg 2007;133:693-700.

24 Mullol J, Fernàndez-Morata JC, Roca-Ferrer J, et al. Cyclooxygenase 1 and cyclooxygenase 2 expression is abnormally regulated in human nasal polyps. J Allergy Clin Immunol 2002;109:824-30.

25 Pujols L, Mullol J, Alobid I, et al. Dynamics of COX-2 in nasal mucosa and nasal polyps from aspirin-tolerant and aspirin-intolerant patients with asthma. J Allergy Clin Immunol 2004;114:814-9.

26 Hulse KE, Stevens WW, Tan BK, et al. Pathogenesis of nasal polyposis. Clin Exp Allergy 2015;45:328-46.

27 Lennard CM, Mann EA, Sun LL, et al. Interleukin-1 beta, interleukin-5, interleukin-6, interleukin-8, and tumor necrosis factor-alpha in chronic sinusitis: response to systemic corticosteroids. Am J Rhinol 2000;14:367-73.

28 Cho DY, Nayak JV, Bravo DT, et al. Expression of dual oxidases and secreted cytokines in chronic rhinosinusitis. Int Forum Allergy Rhinol 2013;3:376-83.

29 Yang YC, Zhang N, Van Crombruggen K, et al. Transforming growth factor-betal in inflammatory airway disease: a key for understanding inflammation and remodeling. Allergy 2012;67:1193-202.

30 Chusakul S, Phannaso C, Tongkobpetch S, et al. Expression of mammaglobins $A$ and $B$ in nasal polyps is similar in patients with and without allergic rhinitis. Am J Rhinol 2008;22:135-8.

31 Castelnuovo P, De Bernardi F, Delù G, et al. Rational treatment of nasal polyposis. Acta Otorhinolaryngol Ital 2005;25(4 Suppl 80):3-29.

Received: October 3, 2018 - Accepted: March 13, 2019

How to cite this article: Pistochini A, Rossi F, Gallo S, et al. Multiple gene expression profiling suggests epithelial dysfunction in polypoid chronic rhinosinusitis. Acta Otorhinolaryngol Ital 2019;39:169-177. https://doi.org/10.14639/0392-100X-2361

Address for correspondence: Andrea Pistochini, Clinica Otorinolaringoiatrica, Ospedale di Circolo e Fondazione Macchi, ASST Sette Laghi Varese, via Guicciardini 9, 21100 Varese, Italy. Tel. +39 0332 278426. Fax +390332 278945. E-mail: docpisto@mac.com 